\title{
Crossed Approach to Social Integration in Europe Examples of Cooperation Between Social Actors
}

\author{
Sihem Anne Essayah \\ U.R.C.A. University, Reims, France \\ Huaiyuan Han \\ Reims Management School, Reims, France
}

\begin{abstract}
In the current uncertain economic situation, a study of European social integration requires different approaches. Within the enlarged European Union, and more particularly in France, to relate it to social policy is of major importance. For European integration aiming redistributing wealth justice, in both business and civil society, and we highlight two categories of actor, respectively participants in social and civil dialogue: the trade unions and social business organisations. The methodology linked to this approach is based on active observation in the fields of trade union work and social business. The interaction between the three components-employment, social rights and solidarity—opens the way for the creation of a new social contract.
\end{abstract}

Keywords: social Europe, coordination, trade unions, social economy, cooperation

\section{Introduction}

Over and above the economic consequences of the 2008 crisis in Europe, necessitating successive aid packages for certain countries, the social fallout is even more serious. A structural approach to this problem seems to be necessary, using national and European mechanisms as socioeconomic buffers. This approach also brings out the role of other non-institutional actors (in meaning of non-public) linked to the world of work and social business.

The European Union, made up of 27 member states, represents a diverse internal market, but with an ageing population. Economic integration is linked to social integration, the lines of which have to be constantly redefined, given the inevitable disparities between the "old" Europe of the Treaty of Rome and the new members.

Several researchers and economists, such as Pigasse and Finchelstein (2009), are in agreement over the fact that a new model for growth has to be invented. A strategy of ever-increasing debt is reaching its limits, but other ways can be investigated to make demand more sustainable. Over the last 20 years, this has been under erosion, with the trend being to reward capital more than work. At the beginning of 2011, the overall unemployment rate

\footnotetext{
Sihem Anne Essayah, Associate Professor, REGARDS Laboratory, U.R.C.A. University, French Red Cross Research, Group Member of the CFE-CGC, Social Security Federation, affiliated to CEC European Managers.

Huaiyuan Han, Professor, Department of People and Organisation, Reims Management School.

Correspondence concerning this article should be addressed to Huaiyuan Han, RMS, 59 rue Pierre Taittinger, 51061 Reims, France. E-mail: huai-yuan.han@reims-ms.fr.
} 
in the euro zone exceeded 10\%, and it is twice as high for the under 25 (European Union data).

The rise of job insecurity and of poor workers is one of the policy priorities of EU 2020. The European Commission set up a European platform for the struggle against poverty and social exclusion in December 2010. It stresses the concept of social innovation through support for small-scale projects, whilst equally giving central importance to the labour market, social protection, education and lifelong learning. These are essential social factors for encouraging sustainable economic development.

A multidisciplinary approach is essential. For a supranational problem, we need a global response which takes account of structural factors in Europe, such as the ageing population and the weakness of industrial infrastructure in certain countries such as France. These characteristics are not always favourable for competitiveness, despite its inclusion in the Lisbon strategy.

The analysis we present below concerns, first of all, the social features of Europe, levers linked to employment, the regulatory framework of Social Europe and the role of the key actors.

The second part of our article will attempt to define the determining factors for social integration. It's a wider meaning than "inclusion" used further, with reference to European rules and institutions. To do this, the role of non-institutional actors will be highlighted — trade unions and social business players—and means of cooperation between these actors.

\section{The Current State of Social Europe}

In our society of abundance and the accumulation of wealth, we can observe paradoxically a continuous rise in precariousness in Europe, there are an estimated 80 million poor. The continuous rise in social spending has not reduced poverty, demonstrating the inefficacity of social policies on certain European countries, including France, despite management methods stressing performance and quantification (Damon, 2010).

The struggle against poverty is founded in the social protection systems of "old" Europe and the ideas of Beveridge or Bismarck, based respectively on national solidarity and a system of insurance. The second system, mainly based on the workforce, is at a disadvantage when employment is low.

\section{Social Problems and Employment Leverage}

The criteria for poverty vary depending on each country's average income and disparities. The United States, the richest country in the OECD, has an average rate of poverty of $17 \%$, which reaches $20 \%$ for children (OECD, 2009).

In most OECD countries, social spending represents on average a third of public spending. Every economy gains by favouring quality employment, the principal source of growth and funding.

Necessary adaptation of social protection system. The social security institutions existing in Europe enable the population to be protected from traditional personal risks related to the lifecycle. In a wider framework of social protection, unemployment compensation and contingency funds may be added to this. Present day society generates new risks related to lifestyle and encouraged by the consumer society.

Between the two methods of financing and cover, insurance or solidarity, the second tends more and more to make up for the insufficiencies of the insurance method, based on contributions and employment.

Europeans, according great importance to their social philosophy, delegate the major part of risk management to the welfare state, in accordance with the principles of national or professional solidarity (Majnoni 
d'Intignano, 1997).

Due to growing unemployment, the social protection model, based on solidarity in most countries among the working population, is sliding towards institutional solidarity between the working and non-working populations. However, the continuing fall in the proportion of the working population and the rise of the non-working ones makes it necessary for national authorities to define new sources of funding.

Moreover, new forms of solidarity deserve to be developed in a common social project, such as forms of civic service, which provide valuable training for the poorly qualified and whose image needs to be enhanced, or solidarity contracts for the unemployed or newly retired.

Necessary dialogue concerning employment. The social dialogue is between the representatives of the employees and the employers. Good relations between the social partners reinforce employee protection while at the same time contributing to competitiveness. Coherent mechanisms for redistribution aim to encourage work; work is regulated by the authorities and must be "decent” according to ILO criteria (Servais, 2004). Current Swedish policy, favouring employment rather than long-term social assistance for those of foreign origin, seems to be bearing fruit, average unemployment rates being below 7\%.

A conflict of different social logics may appear between the normative autonomy of social partners and an active policy of the welfare state. Dialogue between social actors is to be encouraged, with equality of opportunity and treatment as its central theme. This is at the same time a fundamental right and an important factor in the development of professional skills and employability.

For the unemployment, public and also private institutions for professional integration, together with social enterprises, are playing a crucial role. For the young, work placements and day release training programmes are insufficiently developed. Agreements between social partners bringing together on the ground enterprises favouring employment are extremely rare. In order to fulfil the criteria for the quality of work, every job should develop skills to favour future employment. This brings us to look for support from social partners, in particular the unions, who are in a privileged position through their active observation on the ground. Each country must also recognize these actors and facilitate their access to information, without hindrance to the right to trade union activity.

\section{A Structuring Regulatory Framework}

Boulte (2005), a member of the European Anti-Poverty Network (EAPN) has drawn up a pragmatic approach to "Social Europe", explaining that the origins of the construction of Europe are also to be found in social considerations. At each stage of the construction of Europe, from the Treaty of Rome to the Treaty of Amsterdam, then in the Lisbon strategy of 2000, social inclusion is at the heart of European policy.

Europe's social reality is notable for the diversity of its social systems founded on professional relations, employment, social protection, labour rights and including education, training, public health and the struggle against discrimination (Quintin \& Favarel-Dapas, 1999). However, some have doubts about the social integration policy, given the differing characteristics of the various states in a globalized economy (Védie, 2004). In accordance with its constitutional treaty, employment and the improvement of living and working conditions, adequate social protection, social dialogue and the struggle against exclusion are all objectives of the Union.

Social Europe is also a key element in economic transformation, through the modernisation of social 
protection systems. In this domain, negotiation is given an important position, in respect of the principle of free circulation. The working hours directive of 2008, limiting weekly working hours to 48 hours, may be cited as an example of this; it was encouraged by trade unions support, like CFE-CGC in France.

At the same time, economic competitiveness and social progress must be made to converge in a global economy. Indeed, the social partners, including the unions (CES, UNICE...) and the representatives of civil society, (NGO's, social enterprises) have been given a place in the consultation led by the Brussels Commission. (Agreement of 31 October 1991). The European Parliament and the Economic and Social Committee respectively enable civil and democratic dialogue, the definition and elaboration of European social norms. In its green papers, the Union has established mechanisms, including the Open Method of Coordination (OMC), which should encourage support for civil society organizations. The Commission is called to propose methods of funding for the public policies of states and authorities. The integration of different social questions, emphasized above, requires the coordinated intervention of public bodies, social partners and not-for-profit associations, to encourage interaction between politicians and actors on the ground.

However, most of the time, particularly in France, certain actors are not well recognized, such as not for profit associations, which are not included in public policy making.

The European Anti-Poverty Network (EAPN) denounced at the end of 2010 the fact that this mechanism had not been put into practice (EU website) and differing objectives in different countries, such as in the area of measures to boost employment. Here is a lever that can be used to encourage the involvement of social partners defining the orientation of European employment policy, and above all a way to level out the disparities between national models.

The inglorious episode of the "Polish Plumber" during the French debate in 2005, showed the ambiguities of simplistic social stereotypes.

Structural funds are planned to correct regional imbalances, up to $45 \%$ of the community's budget (OECD, 2010). Their promotion and implementation should enable a development of European solidarity, rather than the immediate attractiveness of emerging countries markets. In the long term, it could not harm competitiveness, even for a country such as Germany.

\section{Roles of Key Actors}

A European Forum was held in Strasbourg in 2010 (EU website). One workshop dealt with "Action on the ground beyond the European Year for Combating Poverty and social Exclusion (2010)”.

It is useful to observe how well community mechanisms and propositions put forward are working. This helps us to define in the following section what determines social integration.

Employment is not a protection against poverty: 8\% of Europeans in employment live below the poverty threshold.

Upstream of the EU2020 strategy, the question of European policies in favour of employment and against social exclusion needs to be raised, given that institutional actors find it hard to link employment policy and the problem of poverty.

The relaxation of institutional mechanisms would encourage the involvement of other actors:

(1) Social actors on the ground continuously experiment and develop actions to struggle against social insecurity. The workshop mentioned above, because of the presence of different actors, including trade union 
representatives, enabled a comparison of different perceptions and ideas for their reconciliation to be put forward.

In the fight against poverty, action to reduce the rate of unemployment is not enough; the OMC has demonstrated its deficiencies. Job insecurity increases, sometimes leading States to implement mechanisms, encourage in fact windfall effects or poverty traps. Minimum levels of social benefit are often at a below the poverty threshold level.

Employment is one of several factors of social inclusion. There is also access to education, culture and social protection.

The key to these considerations could be a "formative pathway", allowing people to plan their professional and personal future. On this path, private organizations could have a role as facilitators.

(2) European framework agreements, resulting from social dialogue, such as that concerning the inclusive labour market facilitate the implementation of recommendations. It is therefore the responsibility of social partners and member states to make them work, and so to bring together the economic and social spheres.

Concerning employment, it is better not to remain blocked in narrow ideas of qualifications. The German approach favours the notion of "basic underlying skills", facilitating mobility between closely related jobs, with mostly short training programmes for the acquisition of additional skills.

Within this framework, local actors can respond to calls for projects to experiment and evaluate innovative social practices such as the progress programme, whilst benefitting from community funding. The aim would be to use these associated mechanisms, so as to produce directives or orientation texts for new national public policies aiming at quality employment with working conditions that respect the dignity of the person and are adapted to his/her possibilities.

This interaction with the economic sphere is very important, compared to the risks of the austerity plans dictated by the authorities in Brussels. Hence, as Lefresne and Sauviat (2010) stress, it is important that, in European policy, a correlation could be made between unemployment and structural needs of job market. The longer people remain unemployed, the more their qualifications will lose value, making a return to the job market more difficult.

The above section shows that there are many actors whose objective is social inclusion. However, what would really encourage social integration within the Union is interaction between the different stakeholders.

\section{Determining Factors for Social Integration}

The 2008 crisis revealed the inability of the welfare state system in European countries to ensure efficient regulation so as to avoid social insecurity. Traditional social protection systems, notably in Western Europe, did however act to reduce the effects of the crisis, with minimum levels of social coverage, unemployment benefits and obligatory pension systems.

This also demonstrates how closely linked are the economy and social systems (Laville \& Glémain, 2010), giving a sense to commercial activities.

\section{Development of the Role of Non-institutional Actors}

The complexity of the social system makes it necessary to take into account other stakeholders-non-institutional organizations: the trade unions in the world of work and companies or 
organizations representing vulnerable sections of society. These actors would also benefit from modifying their operating methods to the expectations of those they work for.

Necessary renewal of trade unions. Faced with the problems of the 21st century, it is important to consolidate the professional solidarity between employees, who have been placed in competition with each other by globalization. This can be achieved by internationalising trade unionism, initially within Europe. Hence following the creation of the European of Trade Union Confederation in 1973 (ETUC), the International Trade Union Confederation was founded at the end of 2006 (ITUC). Its objective is to make globalization work in favour of employees, the unemployed and the poor, thus launching a wide-ranging process using the right of collective negotiation with the multinationals (Sohier, 2010).

It is with this perspective that the consolidation of global trade unions into large groups by sector of activity must be seen.

The importance of national trade union action must not be underestimated, but the necessity for better consultation and coordination of union strategies within a wider framework needs to be stressed, so as to combat the risk of competition between workers in different world regions.

The globalization of the economy has resulted in the emergence of other ideological or protest movements within civil society. Through the framework of this new social dynamic, the union movement must rethink its strategy and its methods, or even look to make coalitions. No movement is able to carry a new social project alone at a supranational level.

Such a process will begin at company level, moving from the local to the international dimension, aiming to exercise societal responsibility, to achieve sustainable development. This approach will include in negotiations with the employer, the external consequences of the company's activities. Solidarity will thus be demonstrated between similarly concerned people or groups from different countries.

Support for the social economy. The aim of the social economy is to help to reduce social marginalisation, as much as possible through work. The history of this area of economic activity is linked to that of trade unions, especially in the 19th century, with credit unions and mutual funds. Indeed, it was to combat the excesses of capitalism and job insecurity that these organizations developed.

Present day, mutual organizations are the result of this movement. These structures, in which the economic objective is reconciled with social preoccupations, are made necessary by the lack of various social services. Certain high-profile movements aim to lobby European or international institutions, at world social forums, which gives rise to solidarity at all levels.

The social economy is a definite stakeholder in the movement for social transformation advocated by trade unions such as the CFE-CGC in France-as confirmed at its 2010 congress—or ETUC at the European level.

Alliances need to be made between actors from the unions and the social economy - the former acting within the company, monitoring its level of social responsibility and the latter acting in favour of job creation and employment.

Such actions are usually well received by the young, who are looking for values linked to a societal ideal.

Such a renewal of trade unionism would encourage recruitment, notably in France where the average rate of union membership stands at only $8 \%$. There are multiple reasons for this, which are outside the scope of this article. 


\section{Cooperation to Encourage Social Integration}

Our approach highlights social integration, given that it is a determining factor for economic integration.

There are major disparities in this field, which represent a barrier both to the integration aimed by the European and to the satisfaction of convergence criteria.

The concept of embeddedness developed by Polanyi and Granovetter (Laville \& Glémain, 2010) establishes the relationship between the economic and social sectors.

The interaction between these two dimensions is noticeable above all in the social economy. There, economic activity through employment and production of goods or services is indeed embedded in a social project.

In this framework, the concept of embeddedness highlights social relations and networks, hence the importance given to coordination.

At the European level, the actors do not always find this mechanism satisfactory, but it is a fundamental element to legitimate every form of cooperation between non-institutional stakeholders.

Reconciling governance and social integration. The white paper on European governance published in 2001 set out the principles of legitimacy, efficacy and justice for European civil society and "an integrated notion of European public governance". This is defined by the rules, processes and behaviours that influence the exercise of power at European level.

Whether through deliberative democracy or participation (legitimacy, justice), actors representing civil society, such as social enterprises and trade unions, operate according to this principle. Thus, "European governance should... encourage civil involvement".

To this effect, the European Commission and the other Union institutions need to know how to manage legitimacy, on the basis of the notion of territorial cohesion laid out in the Constitution of the 27 members.

Should we not encourage an evolution of roles, allying trading and non-trading activities, the private and public spheres, companies and civil society?

Centring on the essential components of legitimacy, efficacy and social justice will encourage coherence between the different stakeholders and good governance.

Thus, as put forward by Bonnafous Boucher and Pesqueux (2006), the stakeholder approach, conceived in the 60 (Freeman), is extended to cover the possible interconnection of the public and private spheres, looking for appropriate choices by economic actors and individuals over and above concerns for performance.

Candela Castillo (under the direction of Bonnafous Boucher \& Pesqueux, 2006) links the issue of integration to participative legitimacy. "And so we arrive at the possibility of a European civil society".

The expression of European civil society must be at the centre of governance. This highlights the de facto distancing between European citizens and authorities: the President of the Commission is not for the moment nominated by the European Parliament.

The legitimacy of European governance needs the creation of a public deliberative area; states and central institutions cannot provide a solution to every problem in a global economy.

The constitutional principle of subsidiarity would in fact enable governance to be "reconfigured" so as to be practised at several levels: multilevel governance. The corollary of these measures is the necessary development of territorial cohesion. 
A form of stakeholder self-regulation, more particularly those we have been discussing, would be possible, if the Constitution allowed for their representation in territorial authorities. This would mean a redistribution of power within the framework of a European social project, promoting social justice and equality of opportunity.

Promoting interaction for added social value. The full value of these interactions is seen at the level of stakeholders on the ground, whether they are representatives of the world of work, trade unions or social economy organizations.

Concerning the unions, several analysts advocate the unionising of services, following the example of a study by the French Centre of Strategic Analysis (Verrier, 2010), as a way to revitalise union relationships, after the fashion of the Scandinavian or British "model”, linking union membership with service benefits. Certain proposals have been made in this direction:

- Go further than mere professional activities, by offering services that respond to certain needs of the workers, for example information about improving housing conditions;

- Assist in the management of joint or tripartite bodies to offer, for example, career advice, training or legal services;

- Another area of action, aiming at the mutualisation of services for SMEs and SOHOs, concerns supplementary health insurance and provident schemes.

Certain French trade unions, such as CFE-CGC and UNSA, or teachers' unions, have adopted these ideas, as part of the social field.

Such a strategy is consistent with concerns about social responsibility, and needs to be put forward by companies in their dialogue with their social partners.

Every union can play an active role in the establishment and verification of rules for reducing job insecurity, taking into account changes in the labour and employment market.

Therefore, multiple-based unionism, involving both negotiation and personalised services to its members, can contribute to the setting up of a local network as close as possible to areas of employment.

Along with these forms of actions, certain trade unions are considering possible partnerships with other actors, and notably not-profit organizations.

Concerning social economy organisations or companies, it would be profitable to set up a link with the unions, upstream of the mechanisms for job-finding, for example, based on part management of joint or tripartite bodies, with the aiming of providing coordinated advice for job-searchers.

This could concern public employment agencies, or agencies for the collection of training taxes.

Certain social enterprises are active in these areas, contributing to training and skills development for the disadvantaged.

EMES, the European Research Network (EMES site) defends the necessity of coordinated labour market policies, in order to help a large range of disadvantaged people (unemployed and disabled) who are in danger of being permanently excluded from the labour market and of exclusion from civil society (Spear \& Bidet, 2003).

Groups of social economy organizations are moving in this direction under the acronym WISE (Work Integration Social Enterprises).

Among the largest organizations of the social economy, the French Red Cross is developing innovative experiments together with a group of researchers at Reims University (URCA) to evaluate its governance. This 
development is part of its strategy aimed at encouraging new partnerships.

The actors and organizations presented above have a certain amount of independence as to their operations in relation to public institutions, which facilitate initiatives that contribute to social integration.

Such forms of action are a matter for social entrepreneurs, who consider that the promotion of good practice deserves to be raised to European level, through the OMC, so as to improve reference frameworks and means of action, based on a strategy that has not yet been defined.

For the moment, this has not been put into effect in EU2020 strategy (Pochet, 2010). The director of the European Trade Union Institute highlights the absence of concerned actors—social partners and ministerial representatives from ministries of employment, social security and education—in the labour market reform process.

\section{Conclusion}

The above presentation attempts to highlight issues involved in developing a European social policy based on pluralist principles. It emerges from this that economic progress is indissociable from social regulation that promotes expression and action on the ground by extra-institutional stakeholders.

The foundations of social action, in economies facing the rising of precariousness and persistent or even structural unemployment, are social protection and employment. Given this fact, an alliance between social partners and actors in the social economy is a condition for the reduction of social exclusion.

For this, an institutional European system of coordination needs to be set up via the organization of effective interfaces. A bottom up participative democracy would be a useful development, with active European unions negotiating wide-ranging intra-community agreements on working conditions, health cover for the most vulnerable and social integration.

Moreover, it appears essential for extra-institutional actors to lobby European institutions on social matters, from the perspective of global sustainable development and encouraging long-term rather than short-term financial thinking. This action can be carried forward together with associations of independent company directors, administrators and representatives of civil society.

This position is being adopted more and more by directors of trading companies, notably socially focussed SMEs. A society that functions well in the long-term will also guarantee their durability.

In fact, "shared values", to use Porter's term (Porter \& Kramer, 2011), between all actors-institutions, businesses and extra-institutional actors—can be developed as a virtuous circle, to encourage both economic and social progress by means of social entrepreneurship.

This approach can be made credible within companies by including it as part of their strategy. International consultants currently recommend it to business leaders.

\section{References}

Bonnafous Boucher, M., \& Pesqueux, Y. (2006). Décider avec les parties prenantes (Deciding with the stakeholders). Editions la Découverte.

Boulte, P. (2005). Modèles sociaux européens (European social models). la Tribune Fonda. Retrieved from http://www.fonda.asso.fr

Candela Castillo, J. (2006). Vers une notion intégrée de bonne gouvernance publique européenne (Towards an integrated notion of good European public governance) (pp. 189-211) (Décider avec les parties prenantes, sous la direction de. Bonnafous Boucher, M. \& Pesqueux, Y. ). Editions la Découverte. 
Damon, J. (2010). Eliminer la pauvreté(Eliminating Poverty). PUF.

Laville, J. L., \& Glémain, P. (2010). L'économie sociale et solidaire aux prises avec la gestion (The social economy getting to grips with management). Desclée de Brouwer.

Lefresne, F., \& Sauviat, C. (2010, Novembre). La crise comme révélateur des enjeux de l’Union européenne (The crisis shedding light on issues within the European Union). Chronique Internationale de l'IRES, 127, 56-71.

Majnoni d’Intignano, B. (1997). La protection sociale (Social protection). Editions de Fallois, Sciences Sociales.

OCDE. (2009). Panorama de la société 2009, les indicateurs sociaux de l'OCDE (Overview of Society in 2009, OECD Social Indicators). la Documentation Française

Pigasse, M., \& Finchelstein, G. (2009). Le monde d'après—une crise sans précédent (The world afterwards—An unprecedented crisis). Plon.

Pochet, P. (2010). EU 2020 social impact of the new form of European governance, ETUI Policy Brief, 5, 8. Retrieved from http://www.etui.org

Porter, M., \& Kramer, M. (2011, Janvier-Février). The big idea: Creating shared value. Harvard Business Review.

Quintin, O., \& Favarel-Dapas, B. (1999). l'Europe sociale, Enjeux et réalités (Social Europe-Issues and reality). la Documentation Française.

Servais, J. M. (2004) Normes internationales de travail (International labour standards). Editions L.G.D.I.

Sohier, J. (2010) Le syndicalisme en France (Trade unionism in France), Vuibert

Spear, R., \& Bidet, E. (2003) Le rôle des entreprises sociales dans les marchés européens de l'emploi (The role of social enterprises in European labour markets). European Research Network, Working Papers series, nº 04/01.

Vedie, H. L. (2004). l'Europe à vingt-cinq (Twenty-five nation Europe). Dunod.

Verrier, B. (2010). Le syndicalisme de services: une piste pour un renouveau des relations sociales (The development of trade union services: A way to renew labour relations). La note de veille, Centre d'Analyse stratégique, $\mathrm{n}^{\circ} 190$. Retrieved from http://www.strategie.gouv.fr 